\title{
From post-political to authoritarian planning in England, a crisis of legitimacy
}

Accepted for publication in Transactions of the Institute of British Geographers. The information, practices and views in this article are those of the author(s) and do not necessarily reflect the opinion of the Royal Geographical Society (with IBG).

Authors:

Gareth Fearn (Corresponding author)

School of Architecture, Planning and Landscape, Newcastle University, Newcastle upon Tyne, UK

Email: g.fearn2@newcastle.ac.uk

\section{Simin Davoudi}

School of Architecture, Planning and Landscape, Newcastle University, Newcastle upon Tyne, UK

Article type: Regular paper

Abstract: This paper argues that the crisis of post-politics has sparked an authoritarian turn in spatial
planning in England. That, the proposed reform of the English planning system in 2020 is a defining
moment, marking not only the failure of consensus-seeking politics in governing dissents, but also the
rising authoritarian responses to fix it. This is manifest in the intensification of state control, strengthening of
executive power and decline of democratic institutions, with a shift of emphasis from techno-managerial to

This article has been accepted for publication and undergone full peer review but has not been through the copyediting, typesetting, pagination and proofreading process, which may lead to differences between this version and the Version of Record. Please cite this article as doi: $\underline{10.1111 / \text { TRAN.12501 }}$

This article is protected by copyright. All rights reserved 
executive-punitive practices, and from seemingly consensual to openly antagonistic approaches. This drift to authoritarianism has been justified by invoking a 'state of exception' whereby the established rules and procedures are displaced by the appeal to 'exceptional' circumstances such as, emergencies, national securities, and global pandemics. We draw on a case study of shale gas 'fracking' in England to show how authoritarianism has crept into planning processes through, changes in legislation, reconfiguration of rules, rescaling of decision making, and shrinking of democratic spaces. We discuss the role of a 'political moment' in the politicization of fracking, arguing that the return of the political has engendered antagonistic and exclusionary practices, rather than the agonistic pluralism that planning scholars have called for. In managing planning conflicts, consent, compromise and cooption are increasingly complemented or replaced by discipline, control and explicit exclusion. Instead of denying, neutralizing or suppressing antagonism by calling for consensus, authoritarian politics exaggerates it by establishing frontiers between legitimate and non-legitimate voices of dissents. The paper concludes by emphasizing that the authoritarian turn can only offer a contingent and fleeting solution to the failure of post-political planning to deliver neoliberal pro-growth goals. It cannot eradicate the crisis of legitimacy in planning; nor can it foreclose the political struggle for fixing its meaning and purpose.

Acknowledgments: This paper is based on a Doctoral research project funded by the Economic and Social Research Council (Grant number: ES/P000762/1). We wish to thank, the ESRC for their support, Professor Anthony Zito for his contribution to the discussions on the issues covered in this paper, Professor Matt Sparke (the editor) and four anonymous reviewers for their constructive comments.

Funding information: Research Councils UK > Economic and Social Research Council [Grant number:

This article is protected by copyright. All rights reserved 
ES/P000762/1]

Data availability statement: Due to the nature of this research, participants of this study did not agree for their data to be shared publicly, so supporting data is not available.

This article is protected by copyright. All rights reserved 


\section{INTRODUCTION}

"My friends, I am not a communist. I believe it is also the job of government to create the conditions for free market enterprise" (Johnson, 2020).

If there was ever any doubt about the fallacy of 'rolled back state', the above statement by the British Prime Minister should help to clarify it. From a podium bearing the slogan 'Build, Build, Build', he invoked the 'state of exception' (Agamben, 2005) to make it explicit that, "the times demand a government that is powerful and determined to put its arms around people at the time of crisis", and "to fuel the animal spirits and [...] business investment" (Johnson, 2020). The primacy of the latter was revealed in his plan for the overhaul of the English planning system which was later announced in a White Paper: Planning for the Future. His foreword to the Paper begins with condemning planning as "outdated and ineffective" (MHCLG 2020: 6). Since Margaret Thatcher's ${ }^{1}$ first major attack on planning in the 1980s, these tropes have been used by consecutive governments to not only justify reforms of the planning systems in the United Kingdom (UK), but also demonize the welfare state principles that led to their inception. Boris Johnson's proposed radical reform of English planning, which aims to "tear it down and start again" (Ibid: 6), was previously hinted at by his former chief advisor who pledged to solve "long term problems" such as "the appalling planning system" by "take[ing] an axe to planning laws" (Cummings quoted in Swinford, 2020).

The proposed reform has sparked numerus criticisms from various quarters calling it, a "developers' charter", "the outcome of corporate lobbying powers" and an agenda for "diluting the democratic process" (civil society groups cited in Quinn et al, 2020). We concur with MacFarlane's (2020) suggestion that, "concealed beneath the cuddly rhetoric [...] lies a ferocious attack on democracy". Similar concerns are raised about the suspension or sidelining of democratic safeguards through provisions of the Coronavirus Act 2020 (Ormerod and Davoudi, 2021) and "the widespread uses and abuses of emergency powers during the COVID-19 pandemic" (Thomson and Ip, 2020: 27).

In this paper, we argue that the White Paper is a defining moment in a gradual and ongoing process of change in English planning following the 2007/8 financial crisis and the

This article is protected by copyright. All rights reserved 
introduction of neoliberal austerity measures. That, it marks not only a crisis of legitimacy in post-political planning (Allmendinger \& Haughton, 2011), but also the rise of authoritarian planning. We propose that the failure of consensus-seeking politics in governing dissents has not sparked the agonistic pluralism that some planning scholars have called for. Instead, it has led to antagonistic practices with an intensification of state control and a decline of democratic institutions (Bruff, 2014). That, in the spectrum between consent (understood not necessarily as support) and coercion (understood not necessarily as brute force) in putative liberal democracies, the 'relations of force' (Gramsci, 2003: 175) are drifting towards an authoritarian direction and a 'punitive' phase of neoliberalism "which is organized around an ethos of punishment" (Davies, 2016:124) with intensified and fine-grained 'illiberal' practices (Sparke, 2020).

Drawing on the findings from a case study of planning decisions over shale gas 'fracking' in England, we show how the failure of post-political planning to resolve its irreconcilable conflicts has led to the deployment of authoritarian practices by the government. Fracking represents a 'crucial' case (Gerring, 2007) for understanding the emerging state practices due to its highly contested and polarized nature. The field work for the study was conducted between 2017 and 2020 and involved: 23 in-depth, semi-structured interviews with planners, politicians, industry representatives, and activists at the local and national level; nonparticipant observations and site visits; and, content analysis of key policy documents, government circulars, and records of planning meetings. Data was analyzed thematically using NVIVO software.

The paper is organized around 6 sections. Section 2 provides a brief overview of two dominant liberal perspectives on politics - the aggregative and the deliberative- and the influence of the latter on communicative / collaborative planning theory. In section 3, we draw on the critiques of these perspectives by post-foundational political theories to discuss the crisis of post-political approaches to 'spatial planning' in England in the 2000s. Section 4 is a discussion of how neoliberal attempts to fix the crisis have led to the emergence of authoritarianism. Here, we argue that the English planning system has witnessed a gradual change of emphasis from techno-managerial to executive-punitive practices, and from seemingly consensual to openly antagonistic approaches, both of which are legitimated by the appeal to a 'state of exception'. In section 5, we demonstrate how this change has unfolded in the planning decisions over fracking, highlighting the role of a 'political moment' of

This article is protected by copyright. All rights reserved 
rupture in politicizing fracking and intensifying authoritarian practices. Section 6 concludes the paper by reflecting back on the White Paper to highlight the ongoing political struggles to fix the crisis of legitimacy in neoliberal states.

\section{THE LIBERAL PERSPECTIVES ON POLITICS}

“Planning stands for unresolved conflicts" (Wildavsky, 1973:146)

For more than eight decades planning scholarship has grappled with a key question: how to reconcile competing agendas, contrasting interests, conflictual objectives and diverse aspirations in the political struggles over the ordering of socio-spatial relations. In short, how to govern dissents in putative liberal democracies (Horowitz, 2013). As Aaron Wildavsky (1973) once remarked, planning is politics, to which we add, planning is about politics of place. While this is acceptable to most planning scholars, there remains disagreement about what counts as politics with two liberal perspectives dominating the field for a century: the aggregative and the deliberative (Mouffe, 2005). To contextualize the crisis of post-political and the authoritarian turn in English planning, we provide a brief overview of these perspectives and their influence on planning thoughts.

The aggregative perspective considers politics as establishing a compromise between rational individuals whose interests are aggregated in political parties competing for electoral votes. According to this view of politics, which underpinned the postwar rational planning approaches in the UK, conflicts can be resolved by appealing to the objectivity of technical experts and scientific decision-making processes in which politics has either no place or is an unhelpful interference. In the 1970s, rational planning faced a growing criticism from across the ideological spectrum. Those on the right considered planning - and any form of state intervention- as a threat to the more efficient and morally superior free market (Hayek, 1969). Those on the left dismissed planners' claim to neutrality and saw planning as an apparatus of a capitalist state (Lefebvre, 1991) whose politics was drifting towards, what Poulantzas (1978) called, 'authoritarian statism'.

Among those on the right, Fredrick Hayek's criticism of Keynesian state intervention was particularly influential in providing the intellectual inspiration for the reform of the British planning system by the Thatcher administration in the 1980s. 'Planning under Thatcherism' (Thornley, 1990) was characterized by intensified privatization, deregulation and reliance on

This article is protected by copyright. All rights reserved 
market rationality and its price mechanism. This period of "combative neoliberalism" (Davies, 2016: 124) saw the rolling back of the Keynesian state (Peck, 2012) and a process of "authoritarian decentralism" in planning whereby centralized power was used to downgrade "democracy and involvement" and ensure that "the details of decision-making take place in the de-centralised market-place" (Thornley, 1990:90). Short of dismantling the entire planning system, this 'combative' neoliberalization process antagonized Conservative Party voters without succeeding to deliver capitalist growth (Davies, 1998: 146). To appease their voters and respond to the emerging European Union's (EU) environmental regulatory requirements, a concession was reached to maintain some discretionary limits to private development through local planning powers.

Meanwhile, the critique from the left was developed into communicative / collaborative planning theory by American and European scholars, notably John Forester (1989) and Patsy Healey (1997), whose primary inspiration came from deliberative views of politics and their main advocate, Jürgen Habermas. This deliberative perspective considers politics not as trade-offs and compromises, but as the convergence of preferences towards socially optimal decisions which can be realized through argumentation and 'will formation' in the public domain. It is argued that in the realm of politics a rational moral consensus can be achieved through free and undistorted dialogues. This 'ideal speech situation' is the perquisite for building consensus because, by minimizing "communicative distortions [...] the force of better argument" will prevail (Habermas, 1990:198). Habermas offers a powerful critique of the aggregative views while remaining within the bound of rationality and adhering to the primacy of reason in governing dissents. However, instead of instrumental rationality, his 'discourse ethics' is based on communicative rationality in which politics is seen as a special application of morality. While the aggregative perspective puts the accent on rational calculation and empiricist knowledge to achieve compromise, the deliberative perspective puts the emphasis on moral deliberation and participants' reflexivity to achieve consensus (Mouffe, 2005). Translated into communicative planning, planners were assigned the heroic task of creating undistorted communications to empower participants to "make sense together" (Forester, 1989:119) and create a 'shared language' (Healey,1997). They were identified as honest brokers, mediators, and critical friends whose role was to pave the paths to consensus. Seen as "arbiters of normative standards and guardians of value" (McGuirk, 2001: 198), planners' ultimate goal was to remove conflict and enable consensual "ways of thinking, ways of valuing and ways of acting" (Healey, 1997: 29).

This article is protected by copyright. All rights reserved 
The deliberative perspective provided the intellectual touchstone of the Labour government's reform of planning in 2004 and the introduction of a so called 'spatial planning' system. Although this was defined as an integrative, deliberative and collaborative activity capable of delivering a win-win-win solution to sustainable development, the "high-sounding ideals of planning theory was translated to grubby practices on the ground" (Harvey, 1985:184). Communicative aspirations were "hijacked and misused to promote neoliberal models of spatial development" (Olesen, 2014: 289). Consensual language was used to frame "carefully stage-managed processes with subtly but clearly defined parameters of what is open for debate" (Allmendinger \& Haughton, 2011: 90). As Davies (2016: 127) suggests, this was a period of "normative neoliberalism" during which a deliberative perspective underpinned the 'roll-out' of a neoliberal mode of government (Peck, 2012). Under the banner of modernization, the Labour government launched a rich panoply of technomanagerial approaches to entrench market principles "as the modus operandi of 'governance' and institutional life" (Hall, 2005: 327). Performance indicators against stringent targets and league tables fed into perpetual monitoring and moralistic shaming. The term 'governance' itself became a mark of depoliticization as planners, among others, gave "in to the temptation to replace politics by management, and the exercise of democracy by the awful word 'governance"' (Latour, 2012: 93). 'Matters of concern' to citizens were undermined by 'matters of fact' (Davoudi, 2012). An over-emphasis on expert-led, evidence-based planning enabled 'regulatory capture' by big businesses whose planning applications could benefit from accessing the kind of technical expertise that were not easily available to citizens (Crouch, 2011).

In line with the wider "remaking of subjectivity around the ideal of enterprise" (Davies, 2016:127), a top-down programme of 'culture change' was rolled out to recast the neoliberal pro-growth interests as the public interests which ought to be safeguarded by planners (Clifford, 2012; Davoudi, et al. 2020). Within the 'spatial planning' regime, “consensus formation" became "the grail of much participatory practices" (Hillier, 2003: 424). Conflict mediation, interest brokerage and partnership building were identified as the core skills of planners whose mission was to strike a 'balance' between competing economic, social and ecological interests. In practice, however, rather than creating a stakeholder democracy, partnerships became "a powerful tool for reducing opposition and social conflict" (Blühdorn, 2015: 161) and for determining who constitutes a democratic subject with a legitimate voice. In short, drawing on the deliberative perspecitve on politics to quell dissent to development This article is protected by copyright. All rights reserved 
projects, spatial planning became an instrument of depoliticization (Oosterlynck \& Swyngedouw, 2010; Hilding-Rydevik et al, 2011). A compelling example of this is Baeten's (2012: 247) account of the redevelopment of London's South Bank, where he shows how the participatory processes based on specifically mandated 'dialogue' to achieve 'community partnerships' foreclosed "meaningful disagreement and dispute, and therefore democracy", and how such partnerships often led to the exclusion of supposedly "adversarial agents" as “irrational [...] extremist" (Ibid: 248). The push for consensus redefined communities as either 'responsible' or 'disruptive' depending on whether they agreed or disagreed with redevelopment aimed primarily at capturing real estate value.

Collaborative planning theory itself faced growing criticisms in relation to its theoretical and practical impossibilities of forging undistorted communications (e.g. Huxley, 2000). However, the problem with deliberative ideals is not just the impossibility of consensual politics, but also its desirability for democracy (Mouffe, 2005; Davoudi, 2017). Dissolving the relations of power to reach consensus is not only illusive, but also harmful for democratic institutions of which planning is perceived to be one. This leads to a deeper problem of postpolitical claims made by both aggregative and deliberative perspectives, to which we now turn.

\section{POST-POLITICAL CLAIMS AND THE CRISIS OF THE SPATIAL PLANNING REGIME}

"Extreme ideologising is accompanied by a certain conviction that the "end of ideology' has been reached" (Lefebvre, 1968: 87)

Lefebvre captures the paradox of the claim made by aggregative and deliberative views of politics that ideology is dead, and 'the end of history' is reached (Fukuyama,1989). That, the expansion of globalized capitalism, the collapse of communist regimes, the end of the cold war, the rise of individualism and rationalism, and the formation of evidence-based, expertoriented institutions have made the left - right ideologies redundant (Davoudi, et al., 2020). Both claim that wealthier countries, such as the UK, have reached a post-political era of reflexive modernity (according to Ulrick Beck) and 'third way' politics (according to Anthony Giddens) in which antagonism can be eradicated through either rational calculation (aggregative view) or moral deliberation (deliberative view) (Mouffe, 2005). These postpolitical claims underpinned the formation of both collaborative planning theory and the This article is protected by copyright. All rights reserved 
Labour Government's introduction of the 'spatial planning' regime in 2004 which we mentioned above. Particularly influential for the latter was Giddens' advice on the abandoning of left-right politics in favour of modernized, expert-led, evidence-based and ‘joined-up' policy making. Spatial planning's discourses of integration, collaboration and partnership spoke directly to the invocation of a perceived post-political era in which "partisan conflicts are a thing of the past" (Mouffe 2005: 2).

Renouncing these claims, an alternative perspective on politics has emerged from a diverse set of literature which is rooted in Heidegger's philosophy and known as post-foundational political theories (Marchart, 2007). This perspective is based on a philosophical differentiation between the political as an ontological category (how society is instituted) and politics as an ontic category. The latter refers to "the set of practices and institutions through which an order is created [...] in the context of conflictuality provided by the political" (Ibid: 9). A key tenet of post-foundational theories is that society does not have, cannot have, and will never have a fixed, solid, and ultimate foundation or grounding. As Rancière (1999: 16) put it, politics begins with "the lack of foundation, the sheer contingency of any social order". However, there is always the possibility of 'contingent foundations' (Butler, 1994) whose actualization and sedimentation is the work of the political. Although the political is the moment of the grounding of society, it remains a fleeting and precarious one in the context of ongoing struggle for another, contingent grounding (Marchart, 2007). This relentless tussle for instituting a social order and fixing the meaning and purpose of social institutions (such as planning) is articulated through manifold practices of politics. The political is, therefore, understood not as a space of freedom and deliberation, but as a space of power, conflict and antagonism. Antagonism, seen as "constitutive of human society" (Mouffe, 2005: 9), can take various forms and emerge in diverse social relations, but it can never be eradicated. That is why the political can never be fully foreclosed, and why a consensus-seeking democracy risks becoming radically undemocratic, because "every consensus exists as a temporary result of a provisional hegemony, as a stabilization of power", and "it always entails some form of exclusion" (Ibid).

The Labour government's 'third-way' approach to politics which drew upon both the aggregative and deliberative liberal perspectives, side-stepped fundamental political antagonisms and relied on post-political claims that 'spatial planning' can provide instrumental solutions to avoid the messiness of the political. However, the financial crisis of

This article is protected by copyright. All rights reserved 
2007/8 and the neoliberal austerity measures imposed by the subsequent Coalition ${ }^{2}$ and Conservative governments exposed the limits of the liberal perspectives, challenged the legitimacy of post-political planning, and undermined the principles and proponents of normative neoliberalism. In the search of fixing the post-political crisis, emphasis began to move away from the rhetoric of consensus-seeking towards authoritarian practices, leading to a period of 'punitive neoliberalism' in which "economic dependency and moral failure become entangled in the form of debt, producing a melancholic condition in which governments and societies unleash hatred and violence upon members of their own populations" (Davies, 2016:130). This is a period in which political agonism between adversaries are increasingly turned into moral antagonism between 'friends' and 'enemies'.

In section 5, we draw on the case of fracking to show how this changing emphasis is taking hold in the English planning system. Before that, we clarify what we mean by 'authoritarian turn' at the level of government practices in the UK, while acknowledging that authoritarianism is also present at the level of "the ordinary, the mundane and the everyday operations, flows and embodied performances of illiberalism and illiberal power" (Luger, 2020: 1).

\section{THE AUTHORITARIAN TURN AND A STATE OF EXCEPTION}

The term 'authoritarian' appears to be counterintuitive to liberalism's promise of freeing individuals and markets from the shackles of the 'big state', but appearances can be deceptive. Contrary to being a linear process of increased deregulation and 'smaller state', neoliberalization has been an uneven, uncertain, and meandering process of mutations and adaptations with evolving and overlapping modes of state intervention (Peck, 2012). The need for simultaneous rolling back, rolling out, and rolling over of the state creates the conditions of the possibility of neoliberal authoritarianism. Following the 2008 financial crisis, authoritarian practices have been invoked in the UK as defensive actions to protect capital and fix the post-political crisis of legitimacy.

Thus, to speak of an authoritarian turn is, firstly, not to suggest a departure from neoliberalism, but to mark the crisis-induced reformulation of state's modes of interventions whereby post-political consensual politics is increasingly complemented and / or replaced by "coercive, nondemocratic, and unequal reorganization of societies", leading to "the intensification and extensification of the differences, inequalities, hierarchies, and divisions

This article is protected by copyright. All rights reserved 
that pervade capitalist society" (Bruff, 2019: 375). Secondly, we do not suggest an emergence of something entirely new. On the contrary, the current turn has "strong family resemblances to those that were propagated in neoliberalism's first phases" (Davies, 2016:130) when Thatcherism combined the strong state with the free market, and directed the former against those who resisted or not conformed to the latter. While Thatcher's authoritarian politics was a response to the 1970s' crisis of Keynesian economic management, inflation and unemployment (Poulantzas, 2000), the current turn is a reaction to the 2010s' crisis of neoliberal globalization, stagflation and perpetual austerity (Jessop, 2019). It is a contingent and shaky reaction to post-political crisis of legitimacy; a crisis that is manifest in the erosion of trust in democratic institutions and the opposition against their anti-democratic practices of silencing political dissent in the name of consensus (Bruff, 2014). As in the 1970s, the crisis of legitimacy has not led to the flourishing of emancipatory politics. Instead, it has been predominantly narrated by a powerful right-wing populism where "neoliberal insiders synthetically transform themselves into populist outsiders" (Hendrikse 2018: 170). This "neo-illiberalism" (Ibid) is exemplified by how Boris Johnson won an election in 2019 by using anti-establishment promises of undoing what had been done by his own political party for nearly a decade. The turn to authoritarianism has also reanimated long standing political antagonisms between, for example, the 'citizen' and the 'migrant' (Kundnani, 2021) especially after the EU referendum vote (Freeden, 2017). The "sequence of 'moral panics' around [...] race, law-and-order" which gave Thatcherite's "authoritarian closure" its "gloss of populist consent" (Hall, 1999:151) is now combined with a sequence of 'security panics', around issues such as energy, as we show in the next section on fracking.

Thirdly, authoritarian politics is not limited to the use of extreme and brute force by the state. It can also be enacted through reconfiguration of democratic institutions in such a way that legitimizes exclusion of dissent. Multiple forms of statecrafts are deployed to change laws and regulations, rescale decision making, re-compose committee memberships, and re-define roles and responsibilities (Davoudi and Brooks, 2021). The current turn to authoritarianism resembles Poulantzas's (2000: 203) 'authoritarian statism' which, in response to 1970s' crisis of capitalism, sparked "intensive state control over every sphere of socio-economic life, combined with radical decline of the institutions of political democracy". Today, we are witnessing similar tendencies being foregrounded in response to post-2008 crisis of neoliberalism and its post-political approaches to dissents. Following Brown (2018: 74), "the This article is protected by copyright. All rights reserved 
neoliberal dream has inverted into its own nightmare-authoritarian political culture"; a culture based on "the wholesale rejection of political compromise, concession, and consensus as means of managing dissent" (Peck \& Theodore, 2019: 262). Instead of denying, neutralizing, or suppressing the 'friend-enemy' antagonism through liberal appeals to expertise and rationalism (aggregative perspective) or to consensus and collaboration (deliberative perspective), authoritarian politics exaggerates it by provoking populist attack on perceived 'enemies' (such as 'foreigners', 'underserving poor', 'eco-warriors') and institutionalizing what Ibrahim (2018) calls 'everyday authoritarianism'.

The foregrounding of the state's authoritarian practices in the UK has been legitimated by the appeal to what Agamben (2005: 41-42) calls the 'state of exception'. Unlike Carl Schmitt's (1996) definition, he locates its origin not in dictatorship, but in iustitium or standstill. The invocation of iustitium is "a suspension not simply of the administration of justice, but of the law as such" (Agamben, 2005:42). It is a latent tendency in liberal democracies which can be enacted to resort to "an unprecedented generalization of the paradigm of security as the normal technique of government" (Ibid: 11). Ironically, the state of exception is not an exception or an alternative to the 'normal state', but rather constitutive of it. It is a way of governing by which the established rule of law is displaced by the appeal to 'exceptional' circumstances such as, emergencies, national securities, and global pandemics. In the state of exception, the boundaries between the logic of politics and the logic of war become blurred, and people and places, whose rights are beside the point, are subjected to extra-judicial treatment and violence. Government's intervention through executive decrees becomes the norm. By selectively enacting state's emergency power, certain political subjects are excluded from decision making processes, as we will show in the case of fracking. An example of legitimizing central control in the name of urgency and national security is the formation of a centrally appointed body in 2008 by the UK government to decide on planning applications for major infrastructure development in England; a move described by Johnstone (2010: 98) as an "authoritarian turn in the Labour government's sustainable development policy" to avoid deliberation and delay.

Following the austerity measures, cuts to government expenditure by the subsequent Coalition and Conservative governments have significantly reduced the capacity of local planning authorities (Gray and Barford, 2018). Many planning services and even entire planning departments have been outsourced to private companies, calling into question the

This article is protected by copyright. All rights reserved 
legitimacy of post-political spatial planning. Slade et al. (2019)'s characterization of the 'austerity planner' speaks to a planning system which has been increasingly privatized, lost its capacity and resources, and become more reliant on planning application fees and other payments from developers. In short, the figure of 'austerity planner' symbolizes the crisis of legitimacy in planning and its ability to deliver growth by managing conflicts in favour of neoliberal imperatives.

The strengthening of the central power of state and hollowing out of dispersed and local forms of governance have made planning decisions more open to contestation, making consensual and deliberative planning increasingly untenable (Allmendinger and Haughton, 2011). What we are witnessing is a subtle, yet decisive, change of direction in managing conflicts away from the rhetoric of bottom-up consensus seeking towards top-down executive stipulations. Attention has gradually turned away from obliterating the differences between people and places towards establishing frontiers between what is legitimate concerns and what is not (Mouffe, 2005). Invoking a 'state of exception' has offered a new legitimation strategy for justifying: the spiraling of top-down, central interventions in local planning decisions, the ratcheting up of neoliberal autocratic approaches (Bruff, 2014), the bypassing of civil society groups (Wigger, 2019), and the strengthening of executive powers particularly in response to dissent (Tansel, 2019). Through a series of planning legislation ${ }^{3}$, consecutive governments have gradually removed local planning powers and reinforced central control particularly in relation to major developments such as infrastructure projects which are labelled as 'nationally significant' (Marshall, 2013). These changes have been legitimized by invoking a sequence of security panics around, for example, national need for energy in the face of the perceived threat from foreign suppliers of gas, notably Russia (Bomberg, 2017). The cumulative effects of these reforms have moved politics towards the coercive pole of liberal democratic spectrum, challenging the two dominant liberal perspectives on politics. In English planning, it has pushed consent, compromise, and cooption to the background and pulled discipline, control, and exclusion to the foreground of tackling dissents and silencing oppositional voices. Emphasis has shifted from technomanagerial to executive-punitive actions and from consensual to antagonistic practices, as the following analysis of the case of shale gas fracking will show.

This article is protected by copyright. All rights reserved 


\section{PLANNING AND THE POLITICS OF 'FRACKING' IN ENGLAND}

'Fracking' is a shorthand for a relatively new process of extracting oil and gas onshore from deep lying shale rocks. It involves drilling vertically and then horizontally before injecting a mixture of water, sand and chemicals into the ground under pressure. This type of hydraulic fracturing has been a key driver of oil and gas boom in the United States since 2006 (McLean, 2018), turning the country into the world's largest producer of hydrocarbons (International Energy Agency, 2018). In England, the introduction of shale gas (the focus of our study) occurred shortly after the 2008 financial crash and against the 2008 Climate Act's legally binding targets for reducing greenhouse gas emissions. Shale gas was discursively construed as a 'clean', 'safe and secure' energy that acts as a 'bridge' in the country's 'transition' to 'low-carbon economy' (Bomberg, 2017; Cotton 2017), as stated by the former minister for energy and climate change: "having access to clean, safe and secure supplies of natural gas for years to come is a key requirement if the UK is to successfully transition in the longer term to a low-carbon economy" (Rudd, 2015). In the following account we discuss three distinct phases in the government's fracking policy and related planning contestations in England to show the subtle move from post-political to authoritarian practices.

\subsection{From a moratorium on fracking to its rapid expansion}

The first extraction sites were granted license between 2008 and 2011 without raising many controversies. In 2011, a series of seismic tremors (earthquakes) caused by fracking in Lancashire County (Northwest England) made fracking a national news headline, leading to a nationwide moratorium. This was followed by two technical assessment reports by the Royal Society and Royal Academy of Engineering (2012) and the industry (Green et al., 2012) reassuring the government that the UK regulatory measures can guarantee safe fracking. A leaked letter in 2014 from the former Chancellor asked ministers to ensure that regulators "have the necessary skills and resources in place to publicly defend the robustness and safety of the regulatory regime" (Osborne quoted in Carrington, 2015). However, this appeal to the authority of experts failed to depoliticize contestations over fracking between local communities, environmental groups, local and central governments, and the industry ${ }^{4}$ (Williams et al., 2017; Drake, 2018). In response to the failure of post-political approaches, more authoritarian modus operandi were invoked in the second and third phases.

This article is protected by copyright. All rights reserved 
Despite a growing opposition (Keeler, 2016; Speed, 2018), the government lifted the moratorium in December 2013 and announced its intention for "going all out for shale", as former Conservative Prime Minister put it (Cameron quoted in Watt, 2014). This declaration was not a matter of public dialogue and consent, but a top-down economic policy that government was determined to implement by all means including a reconfiguration of democratic processes and institutions. Thus, a series of pro-fracking measures were introduced such as, tax breaks, incentives for austerity-induced cash-strapped local authorities, and paybacks to affected communities in an attempt to develop a 'social license to operate' (Bradshaw and Waite, 2017) and give the regulatory and planning reforms a "gloss of populist consent" (Hall, 1999: 151). Marginalized regions were prioritized for fracking on the assumption that they would not attract objections. This, however, proved wrong as the public uproar against the remark by the Conservative Peer and former government's energy advisor showed. He claimed that, "there are large, uninhabited and desolate areas. Certainly in part of the North East where there's plenty of room for fracking" (Howell quoted in BBC News, 2013), mentioning Lancashire specifically to describe these areas as "unloved places that are not environmentally sensitive" (Cotton, 2017: 192).

One of the most radical planning reforms in relation to fracking was the passing of the Infrastructure Act 2015. Despite major opposition from within and outside Parliament, it gave the industry the right to horizontally drill underneath people's property without the landowners' permission and in protected areas such as National Parks (Whitton et al., 2017). The Act legalized what was previously illegal, despite oppositions by 99 percent of the 40647 responses to consultation (Cotton, 2017). This and other provisions of the Act indicate a shift from seeking win-win-win solutions to sustainable development to outright preferences for fossil-fueled economic growth, as is vividly illustrated by the reaffirmation of the role of ministers in "maximize[ing] economic recovery of UK petroleum" (Infrastructure Act, 2015: Part 6, s41). This reconfiguration of rules and regulations was followed by new ministerial requests for fast tracking planning decisions on fracking.

\subsection{A 'political moment' of rupture}

In 2016, the Conservative government's overturn of local authority's decision to reject the planning application for Preston New Road (PNR) site in the Lancashire County sparked 'a political moment' of rupture, radically politicizing the growing conflicts and opening a space for "proper political framing" (Swyngedouw, 2010: 214) of shale gas planning. Despite This article is protected by copyright. All rights reserved 
planners' attempts to dismiss the seismic risks as either "perceived fears" that "cannot be supported by independent review and guidance", or preventable by technical expertise and adequate regulatory framework (Lancashire County Council, 2015: 57), contestations moved from the local to the national level and was staged at not only planning arenas, but also the wider public sphere. Consensus seeking rhetoric turned into antagonistic practices of heavily policed national protests (Netpol, 2017). Conflicts became polarized into pro- and antifracking camps with two opposing storylines: shale as 'Opportunity' and shale as 'Threat' (Bomberg, 2017). Instead of leading to agonistic politics, the return of the political unleased an array of authoritarian approaches which by the time of writing (2021) have become prominent features of many planning processes.

PNR was one of the first sites to be considered for shale gas exploration following the lifting of the moratorium in 2012. Determining its planning application took nearly one year, involved an unusual process of seeking legal advice by the three main parties ${ }^{5}$, and was described by one local councilor as "one of the most difficult things any of us have ever done in our lives" (Unknown Author, 2016). It attracted contradictory evidence for and against the safety of fracking with the latter being dismissed as driven by political motives (Short and Szolucha, 2019). In June 2015, the application was rejected by local councilors against the advice of their planning officers (Lancashire County Council, 2015). Subsequently, the applicants appealed, and the Council's decision was overturned by the planning minister in 2016 (DCLG, 2016). While this is not an unusual process in the English planning system, it does stand out as an example of creeping authoritarianism given the unconventional and intensified form of intervention by government ministers. The then responsible ministers for energy and for planning issued a joint statement a few weeks after Lancashire Council's decision. Using disciplinary and punitive language, the statement warns that, "ministers want to ensure shale applications can't be frustrated by slow and confused decision making amongst councils" (Rudd and Clark, 2015). Once the Parliament returned from its summer recess, each minister produced a written ministerial statement for the House of Commons. The planning minister set out his intention to use his power to intervene whenever local authorities were "underperforming" and not processing shale gas applications quickly enough (Clark 2015). The energy minister rendered her statement the status of 'a material consideration' for all future planning decisions on shale gas (Rudd 2015). Since 2010, ministerial statements have been increasingly afforded the same weight in planning decisions as formal policies without being scrutinized through formal democratic processes.

This article is protected by copyright. All rights reserved 
The ministerial intervention was legitimized by invoking a state of exception and the "national need to explore our shale gas and oil reserves" (Rudd, 2015). The significance of this intervention became apparent at the appeal inquiry for the PNR site. Focusing heavily on its wording about the 'national need', discussions were dominated by the interpretations of two opposing camps. Cuadrilla, the fracking industry, argued that the statement "must be given considerable weight", while the Lancashire County Council's representative argued that its weight should not be "exaggerated" (Hayhurst, 2016). Despite considerable doubts being raised about its status, the ministerial statement was put on a par with formal national policies. The Minister and the Planning Inspectorate ${ }^{6}$ concluded that the national need for gas trumped the locally specific reasons (such as noise and traffic) for rejecting the application (DCLG, 2016) while the impact of shale gas on climate change was considered as either irrelevant or lacking the evidence base.

\subsection{Deepening of antagonistic practices}

In 2018, the proclamation of 'slow and confused decision making' in planning was used in another joint ministerial statement (Brokenshire and Clark, 2018) to mobilize a wider reform of planning. If successful, this would have: a) added the exploratory phase of fracking in the expanding field of Permitted Development Rights (PDRs), and b) included its final production phase in Nationally Significant Infrastructure Projects (NSIPs). The former would have given the developer a carte blanche, and the latter would have removed local authority's decision-making power and placed it in the hands of central government and its appointed commissioners. It transpired that these proposals had been on the government's agenda for several years and described as a "plot to foil anti-frackers" (Hope cited in Cotton, 2017). The joint statement also warned local authorities to "avoid undue sterilisation" of local plans (Brokenshire and Clark, 2018, n.p.). Given that it was published at the time when a Select Committee Inquiry (HCLG Committee, 2018) was concluding its recommendations on the reform of the planning process for shale gas, it is hard not to infer that the ministerial statement was rushed through to influence the outcome of the inquiry.

The proposal to make fracking a subject of PDRs and NSIPs deepened antagonistic practices. It was met with a strong backlash from local councils (including Conservative-led councils) who were concerned about losing their decision making power over fracking. Given that at the time the Conservative government did not have a parliamentary majority, a small rebellion from backbenchers could have blocked the legislation. As one Member of This article is protected by copyright. All rights reserved 
Parliament (MP) put it, successful lobbying of anti-fracking groups (such as Frack Free and United) and NGOs (such as Friends of the Earth) had led to "an informal network of 20/30 MPs who really didn't like it, and another 20 or so MPs who were on the periphery that didn't like some elements of it, and it became perfectly clear [...] that nothing would get through" (Interview, January 2020). Environmental groups joined the discontent, stating that, "Fundamentally, we cannot see how replacing local authority planning oversight of this type of development can be seen to be compatible with maintaining the integrity of local democratic planning" (CPRE, 2018).

Even some members of the fracking industry were concerned that antagonistic interventions by the government could diminish the legitimacy of fracking, stating that,

"do I believe that permitted development is the way to get around all of that and win a SLO [Social License to Operate]? Well, there's two ways to look at that, one no [...] because it doesn't really involve the community [...] it sort of rides roughshod over their ability to have their stakeholder voice in what's going on" (Interview, September 2018).

A crucial discursive shift in the re-politicization of fracking was its framing by the antifracking movements as an attack not just on local and global environmental concerns, but also on democracy. This shift in framing forged a connection between a perceived local planning issue and the wider criticisms of democratic deficits, manifested by the state's heavy and violent policing of the protests (Netpol, 2017) and the arresting of four antifracking activities who were later released on appeal (Hawkins, 2019). The last time when environmental protestors were imprisoned was 1932, so the arrest was almost unprecedented, as argued by one of the activists involved in the PNR site,

\footnotetext{
"very quickly realised that the states agenda and people's agendas are quite different, I mean I've been on demonstrations before, and I've encountered the police before, but never in the way that I've encountered them on PNR" (Interview, January 2018).
}

This article is protected by copyright. All rights reserved 
The heavy policing of the protests across England was followed by new pre-emptive injunctions taken out on 'persons unknown' in order to prohibit future protests at fracking sites and charge the protesters with 'contempt of court'. ${ }^{7}$ These authoritarian responses to political contestations are captured in the following statement by a member of an environmental group.

Firms started "reaching out for these injunctions against persons unknown straight away, as I said it's not in response to things that have happened, it's not against people they think are problematic, it creates a whole atmosphere of fear and intimidation against people who would want to show their right to lawful ways to protest" (Interview, April 2019).

The state's response was a mark of eroding democratic rights and diminishing trust in democratic planning processes. Engaging in a dialogue about fracking turned into fighting a battle which the government was determined to win as the former Prime Minister's declaration of 'all out for shale' made it clear: "Fracking has become a national debate [...] and it's one that I'm determined to win. [...] Without it, we could lose ground in the tough global race" (Cameron, 2013). In this battle, the protesters were identified as 'enemies' of local communities. Their actions were framed as a threat to energy security, national sovereignty, and independence from foreign supplies, notably gas from Russia with which the geopolitical relationships were at a low point (Beebeejaun, 2017). Articulating adversaries as irrational and disruptive extremists is a key discursive practice of exclusion, as shown by Baeten's (2012) study mentioned earlier. In the case of fracking, the antagonistic practice of dividing up the adversaries into 'local communities' and 'protestors' and pitting one against the other was used by the subsequent Energy Minister who stated in the Parliament that,

"Frankly, I pity any local councilor who gets an application on their desk, because they will shortly have a travelling circus of protestors to deal with, most of whom do not hail from the areas where these sites are located.” (Perry 2018)

The Minister also used the 'divide and rule' tactic to legitimize the unsuccessful move to include fracking in PDRs and NSIPs, discussed above. In an article in The Sun, she defended that proposal and the removal of planning powers over fracking from local authorities, on the ground that "protestors from out of town" had created "a morass of protest and countervailing information" corrupting the planning process (Ibid).

This article is protected by copyright. All rights reserved 
Instead of the post-political promise of knowledge sharing, the publication of the report on the impacts of fracking on rural areas was held back until after the PNR appeal because, its findings could have vindicated much of the local residents' concerns about the site (Bradshaw and Waite, 2017). The rhetoric of transparency and collaboration gave way to the control of information flows, and re-configuration of rules through ministerial interventions in favour of the industry; all of which justified on the basis of a perpetual state of exception. The apotheosis of such regulatory reformulations was the insertion of a paragraph in the National Planning Policy Framework (NPPF) in 2018. Using the industry-produced figures on emissions and reiterating their claim that fracking reduces "dependency on foreign supplies of gas" (Arup \& Cuadrilla Resources, 2014: 5), the paragraph re-enacts the 'security panics', arguing that,

\begin{abstract}
"Minerals planning authorities should: recognize the benefits of on-shore oil and gas development, including unconventional hydrocarbons, for the security of energy supplies and supporting the transition to a low-carbon economy; and put in place policies to facilitate their exploration and extraction.” (NPPF, 2018: 61)
\end{abstract}

An activist group, Talk Fracking, successfully challenged this paragraph at the High Court. The Court considered it to be "so flawed in its design" that it was "unlawful" (Claire Stephenson V Secretary of State for HCLG: 34) due to its limited consultation and the failure to take account of new research rebutting the industry's claims about fracking being 'low carbon'. The judge ruled that, "scientific evidence as described in their [Talk Fracking's] consultation response, was never in fact considered relevant or taken into account" by the government (Ibid: 35). The government's attempt to insert a pro-fracking paragraph into the NPPF without sufficient consultation was an authoritarian reaction to the failure of post-political planning to foreclose politics and stage-manage the 'unruly' opposition to comply with its neoliberal pro-growth and climate-blind agenda through formulaic approaches to communicative planning. A new form of statecraft was devised to diffuse the fracking conflicts and regain legitimacy.

In a purported attempt to diffuse the conflict over fracking, a former Labour MP who lost her seat while - against her Party's policy- supporting a fracking site in her constituency was appointed as a 'shale gas commissioner'. Her role was to: act as a "contact point for residents, listen to their concerns, refer them to relevant and factual research and help

This article is protected by copyright. All rights reserved 
improve communication with regulators and industry" (BEIS, 2018). She met with the relevant industry, regulatory bodies, and local activist groups, but made it clear that the latter should include only the 'acceptable anti-frackers' and not the 'unruly' ones, as a local activist put it:

"the thing is [...] every meeting we've had, everyone has expressed, and had documents, and had the research to back up their view, and I don't know what she expects, if she won't meet with people because she doesn't want it to 'get shouty', what does she expect, she's not gonna hear anything different" (Interview, January 2018)

This explicit exclusionary practice of defining who is a democratic subject and has the right to take part in the fracking disputes is a deviation from post-political pretense of seeking consensus and making compromises to reach win-win outcomes. After about six months, the commissioner resigned on the basis that: "a perfectly viable industry is being wasted because of a Government policy driven by environmental lobbying rather than science, evidence and a desire to see UK industry flourish" (Engel quoted in Hayhurst, 2019). Accoring to her, the "environmental lobby" did not "represent local residents, nor the wider population" but were out to "fill their coffers" with an intransigent demand to end the use of fossil fuel (Ibid). Her frustration at the government stemmed from its refusal to adjust the regulatory limits for acceptable levels of seismicity. This became particularly pertinent when a second set of tremors in 2019 damaged houses near the PNR site. This event along with the upcoming General Election in which the government claimed to be "led by the science" (Leadsom, 2019) triggered another moratorium on shale gas based on the geological unsuitability; a concern that had been raised repeatedly by the NGOs and activists for nearly a decade. As of 2021, the moratorium is still in place, giving the impression that the state has lost its selfdeclared battle of 'all out for shale'. However, what is less certain is whether it will win 'the war' of institutionalizing the authoritarian turn in planning. This depends largely on the outcome of the White Paper's proposed reform of the English planning system (MHCLG, 2020) with which we started this paper and to which we now return.

\section{CONCLUSION}

Since its inception, attempts have been made by various governments to fix the meaning and purpose of planning as a key institution of liberal democracy in Britain. Although governing This article is protected by copyright. All rights reserved 
dissents has remained a core purpose of the planning system, defining ways of doing so have led to multiple competing views with two liberal perspectives dominating the articulatory space: one appeals to the instrumental rationality and objectivity of expert decisions to seek compromise, and the other lean on the communicative rationality of deliberation to seek consensus. By replacing the political with technical calculations or moral deliberations, both depoliticize what is inherently and inescapably political. The failure of these approaches to fix the crisis of legitimacy in English planning reached a new height after the 2008 collapse of financial institutions and austerity measures, leading to the crisis of post-political planning and an authoritarian turn. The disenchantment with democratic institutions and their exclusionary practices have been largely narrated by a rising authoritarian populism which has sharpened the frontiers of politics and ignited multiple battles between 'enemies' and 'friends'. In the dynamic and contingent spectrum between consent and coercion, we are witnessing a drift towards the latter as the main technique of governing dissents.

Our analysis of fracking policy provides an example of this drift in English planning. It shows how government policy shifted from a moratorium on fracking to 'all out for shale gas' and back to moratorium again. The self-declared battle, which the government was determined to win as part of its attempts to fix the 2008 crisis of capitalism, was a clear departure from post-political spatial planning and a sign of creeping authoritarian practices. Techno-managerial approaches of stage-managing dissents were largely replaced by punitive measures and top-down, executive stipulations. Concession and compromise for resolving conflicts were rejected in favour of outright exclusion, ministerial statements, and centralized decisions. Political differences over the environmental versus economic implications of fracking were antagonized into a battle between the anti- and pro- fracking camps with final decisions often being taken not in planning arenas, but in the court of law. Punitive measures were deployed to silence dissenting voices and make local authorities comply with central government policies.

The authoritarian turn has been legitimated by invoking a state of exception in which a series of security panics are constructed to legitimate its antagonistic and undemocratic practices, and give it a gloss of populist consent. In the case of fracking, opposition to fossil-fuel extractions were framed as a threat to national security. Political adversaries were portrayed as 'enemies' of the public interest whose anti-fracking actions were not only harming local communities in need of jobs, but also making the country dependent on foreign supply of gas.

This article is protected by copyright. All rights reserved 
Protesters were divided into 'civilized' and 'unruly' with the latter being explicitly excluded from deliberations and even imprisoned. Despite all these, the government eventually conceded to the anti-fracking movement, and in an attempt to regain legitimacy had to find refuge in 'science' and geological unsuitability for declaring a new moratorium on fracking. The anti-fracking movement were able to exploit the gaps created by deregulation, funding cuts and the crisis of legitimacy in planning decisions. This implies that the government has lost the battle over fracking, but it is important to note that it may still win the war over planning, especially if the White Paper's proposals are implemented. Some of these proposals indicate a stronger drift to authoritarian planning and the removal of the limited avenues for dissent, such as those utilized by anti-fracking groups.

The White Paper was issued in the middle of a global pandemic which elevated the postausterity state of exception to new heights. This is not surprising given the role played by planning in Boris Johnson's economic recovery plan that is reliant on a 'Build Build Build' agenda. His promise to "unleash Britain's potential" (MHCLG, 2020: 16) is based on taking a "scythe to red tape and get things done" (Johnson, 2020). The Paper sets out a "rule based" (MHCG, 2020: 18) approach which from the outset determines what is an acceptable development in an area while proposing to expand Permitted Development Rights. Planning decisions are to become more centralized by making the NPPF the primary source of planning policies. This is justified on the ground that "democratic accountability" is equated with "Ministers' responsibility for planning decisions" (Ibid: 16). Punitive measures will be reinforced through central governments' intervention in planning decisions if local authorities are perceived to be slow. Importantly, the government is also consulting on changing the role of judicial review which could limit some of legal challenges that were used in the case of fracking (MoJ, 2020). The planning system is articulated as an outcome of "decades of complexity and political argument" (MHCLG, 2020:16) highlighting specifically the vagueness of 'sustainable development' which is to be redefined to "remove any debate about this descriptor" (Ibid: 28). Signaling a turn towards centralized and exclusionary practices of 'divide and rule', the figure of 'protestors from out of town' is invoked to claim that deliberative planning meetings "allow a small minority of voices, some from the local area and often some not, to shape outcomes" (Ibid: 20). In a stark rebuke of deliberative perspectives, authoritarian interventions are to be used to foreclose the limited political spaces of post-political planning and explicitly silence or de-legitimize dissenting voices. Free market think-tanks and newspapers have articulated these changes as 'liberalization' This article is protected by copyright. All rights reserved 
(Payne, 2020). We see them as centralization and intensification of state control in the vein of authoritarian statist's responses to a crisis of legitimacy. The proposed reform, which has been further formalized in latest amendments to the NPPF (MHCLG, 2021: 12), would make it easier for ministers to take executive and punitive decisions, change the rules on the fly, and use antagonistic practices to delegitimize political oppositions. Somewhat ironically, this latest instantiation of neoliberal reform leads us closer to the very "socialist" problems that Thatcher railed against, i.e. excessive central government power, corruption, and constraints on citizens' freedom of expression.

As we argued at the beginning of this paper, the White Paper is a defining moment in the crisis of post-political planning. If implemented, it will institutionalize and normalize an authoritarian neoliberal planning in ways that the Thatcher administration failed to do in the 1980s. The Paper epitomizes the creeping of authoritarianism into democratic institutions and processes not necessarily through brute force, but through cumulative changes to legislation, reformulation of rules, rescaling of decision making, reconfiguration of institutional norms and practices and re-composition of who is accountable to whom. Riding the wave of rightwing populism and the need for post-pandemic economic recovery, the neoliberal state can draw on a heightened 'state of exception' to fix the post-political crisis, but this will only be a contingent and fleeting settlement. Sooner or later, the authoritarian solutions will face their own crisis of legitimacy. What we have shown here is a glimpse of the ongoing process of authoritarian neoliberalisation in planning- as in many other areas - in which the vestiges of liberal democratic institutions are being slowly cannibalized to maintain the politicaleconomic status

quo.

\section{ENDNOTES}

1 British Prime Minister 1979 - 1990

2 Liberal Democrat-Conservative Government 2010-2015

3 Notably the Planning Act 2008, the Localism Act 2011, and the Infrastructure Act 2015

4 Notably Cuadrilla Resources that owns licenses to test drill for shale gas in the UK

5 Lancashire County Council, Friends of the Earth, and Preston New Road Action Group

6 A centrally appointed body dealing with planning appeals

This article is protected by copyright. All rights reserved 
7 This would mean protestors could face significant fines, asset seizure, and a custodial sentence of up to 2 years

\section{REFERENCES}

Agamben, G. (2005). State of exception. Chicago: University of Chicago Press

Allmendinger, P., \& Haughton, G. (2011). Post-political spatial planning in England: a crisis of consensus? Transactions, 37(1), 89-103. https://doi.org/10.1111/j.14755661.2011.00468.x

Arup, \& Cuadrilla Resources. (2014). Environmental Statement. Retrieved from https://cuadrillaresources.com/wp-content/uploads/2015/02/PNR-ES.pdf

BBC News. (2013). Fracking OK for 'desolate' North East, says Tory peer. Retrieved from https://www.bbc.co.uk/news/uk-politics-23505723

Beebeejaun, Y. (2017). Exploring the intersections between local knowledge and environmental regulation: A study of shale gas extraction in Texas and Lancashire. Environment and Planning C: Politics and Space, 35(3), 417-433. https://doi.org/10.1177/0263774X16664905

Blühdorn, I. (2015). Post-Ecologist Governmentality: Post-Democracy, Post-Politics and the Politics of Unsustainabilty. In J. Wilson \& E. Swyngedouw (Eds.), The Post-Politcal and its Discontents: Spaces of Depoliticisation, Spectres of Radical Politics Edinburgh: Edinburgh University Press. 146-166

Bomberg, E. (2017). Shale We Drill? Discourse Dynamics in UK Fracking Debates. Journal of Environmental Policy \&amp; Planning, $\quad$ 19(1), 72-88. https://doi.org/10.1080/1523908X.2015.1053111

Bradshaw, M., \& Waite, C. (2017). Learning from Lancashire: Exploring the contours of the shale gas conflict in England. Global Environmental Change, 47 (Supplement C), 28-36. https://doi.org/10.1016/j.gloenvcha.2017.08.005

This article is protected by copyright. All rights reserved 
Brokenshire, J., \& Clark, G. (2018). Energy Policy:Written statement - HCWS690. Retrieved from https://www.parliament.uk/business/publications/written-questions-answersstatements/written-statement/Commons/2018-05-17/HCWS690/

Brown, W. (2018). Neoliberalism's Frankenstein: Authoritarian Freedom in Twenty-First Century “Democracies”. Critical Times, 1(1) https://doi.org/10.1215/26410478-1.1.60

Bruff, I. (2014). The Rise of Authoritarian Neoliberalism. Rethinking Marxism, 1-17. https://doi.org/10.1080/08935696.2013.843250

Bruff, I. (2019). Overcoming the Allure of Neoliberalism's Market Myth. South Atlantic Quarterly, 118(2), 363-379. https://doi.org/10.1215/00382876-7381194

Butler, J. (1994). Contingent foundations: Feminism and the question of 'postmodernism'. In S. Seidman (Ed.), The Postmodern Turn: New Perspectives on Social Theory. Cambridge: Cambridge University Press. 153-170

Cameron, D. (2013). We cannot afford to miss out on shale gas. Daily Telegraph Retrieved from https://www.telegraph.co.uk/news/politics/10236664/We-cannot-afford-to-miss-out-onshale-gas.html

Campaign to Protect Rural England. (2018). Permitted development for shale gas exploration, a consultation response from CPRE. Retrieved from https://www.cpre.org.uk/resources/permitted-development-for-shale-gas-exploration/

Carrington, D. (2015). George Osborne urges ministers to fast-track fracking measures in leaked letter The Guardian. Retrieved from https://www.theguardian.com/environment/2015/jan/26/george-osborne-ministers-fast-trackfracking

Claire Stephenson V Secretary of State for Housing and Communities and Local Government (2018), High Court of Justice (U.K.), Case EWHC 5119. Retrieved from https://www.bailii.org/ew/cases/EWHC/Admin/2019/519.pdf

Clark, G. (2015), Planning for Onshore Oil and Gas: Written Statement - HCWS201. Retrieved from https://questions-statements.parliament.uk/written-statements/detail/2015-0916/HCWS201

This article is protected by copyright. All rights reserved 
Clifford B.P. (2012) Planning in an age of customers: British local authority practitioners, identity and reactions to public sector reform. Town Planning Review 83(5): 553-574. https://www.jstor.org/stable/23325600

Cotton, M. (2017). Fair fracking? Ethics and environmental justice in United Kingdom shale gas policy and planning. Local Environment, 22(2), 185-202. https://doi.org/10.1080/13549839.2016.1186613

Crouch, C. (2011). The strange non-death of neoliberalism. Cambridge: Cambridge : Polity.

Davies, H. W. E. (1998). Continuity and Change: The Evolution of the British Planning System, 1947-97. The Town Planning Review, 69(2), 135-152.

Davies, W (2016). A New Neoloberalism, New Left Review. 101 Sep-Oct 121-134

Davoudi, S. (2012) The legacy of positivism and the emergence of interpretive tradition in spatial planning, Regional Studies, 46(4):429-441 https://doi.org/10.1080/00343404.2011.618120

Davoudi, S. (2017) Spatial Planning: the promised land or roll out neoliberalism? in Gunder, M. Madanipour, A. and Watson V. (eds.) The Routledge Handbook of Planning Theory, 1528

Davoudi, S. and Brooks E. (2021) City-regional imaginaries and politics of scalar fixing, Regional Studies, 55(1)52-62 https://doi.org/10.1080/00343404.2020.1762856

Davoudi, S. Galland D. and Stead D. (2020) Reinventing planning and planners: ideological decontestations and rhetorical appeals, Planning Theory, 19(1):17-37 https://journals.sagepub.com/doi/10.1177/1473095219869386

Department for Business Energy and Industrial Strategy (BEIS). (2018). Natascha Engel appointed as Commissioner for Shale Gas. Retrieved from https://www.gov.uk/government/news/natascha-engel-appointed-as-commissioner-for-shalegas

Department for Communities and Local Government (DCLG). (2016). Recovered appeals: Cuadrilla Bowland Ltd and Cuadrilla Elswick Ltd (refs: 3134386, 3130923, 3134385, 3130924 - 6 October 2016). Retrieved from This article is protected by copyright. All rights reserved 
https://assets.publishing.service.gov.uk/government/uploads/system/uploads/attachment_data /file/558278/16-10-06_DL_Cuadrilla.pdf

Drake, F. (2018). Risk Society and Anti-Politics in the Fracking Debate. Social Sciences, 7, 222. https://doi.org/10.3390/socsci7110222

Forester, J. (1989) Planning in the public domain, University of California Press: Berkeley, CA

Freeden, M. (2017). After the Brexit referendum: revisiting populism as an ideology. Journal of Political Ideologies, 22(1), 1-11. https://doi.org/10.1080/13569317.2016.1260813

Gerring J (2007) Case Study Research: Principles and Practices. Cambridge: Cambridge University Press.

Gramsci, A. (2003). Selections from the Prison Notebooks (Q. Hoare \& G. Nowell-Smith, Trans. Q. Hoare \& G. Nowell-Smith Eds.). London: Lawrence and Wishart.

Gray, M., \& Barford, A. (2018). The depths of the cuts: the uneven geography of local government austerity. Cambridge Journal of Regions, Economy and Society, 11(3), 541-563. https://doi.org/10.1093/cjres/rsy019

Hall, S. (1990) The hard road to renewal, London: Verso

Hall, S. (2005). New Labour's Double-shuffle. Review of Education, Pedagogy, and Cultural Studies, 27(4), 319-335.

Habermas, J. (1990) Moral consciousness and communicative action, MIT Press: Cambridge Mass.

Harvey, D. (1985) The Urbanisation of Capital, London: Blackwell

Hawkins, J. (2019). Case comment - Fracking and the scope for public dissent: The sentencing of The Frack Three (Richard Roberts, Simon Blevins, Richard Loizou, (Case Number T20180167)) and R v Roberts (Richard) [2018] EWCA Crim 2739. Environmental Law Review, 21(2), 128-135. https://doi.org/10.1177/1461452919842434

Hayek, F. A. v. (1969) Studies in philosophy, politics and economics. Touchstone.

This article is protected by copyright. All rights reserved 
Huxley, M. (2000) The Limits to Communicative Planning, Journal of Planning Education and Research, 19:369-377. https://doi.org/10.1177/0739456X0001900406

Hayhurst, R. (2016). Live updates from the final day of the Cuadrilla fracking inquiry. DrillorDrop. Retrieved from https://drillordrop.com/2016/03/16/live-updates-from-the-finalday-of-the-cuadrilla-fracking-inquiry/

Hayhurst, R. (2019). Shale Gas Commisioner Resigns. DrillorDrop. Retrieved from https://drillordrop.com/2019/04/28/shale-gas-commissioner-resigns/

Healey, P. (1997). Collaborative planning : shaping places in fragmented societies. Houndsmills, England: Macmillan.

Hendrikse, R. (2018). Neo-illiberalism. Geoforum, 95, 169-172. https://doi.org/10.1016/j.geoforum.2018.07.002

Hilding-Rydevik, T., Håkansson, M., \& Isaksson, K. (2011), The Swedish Discourse on Sustainable Regional Development: Consolidating the Post-political Condition. International Planning Studies, 16(2), 169-187 https://doi.org/10.1080/13563475.2011.561062

Hillier, J. (2003) 'Agon'izing over consensus: Why Habermasian ideals cannot be 'real'. Planning Theory 2(1): 37-59. https://doi.org/10.1177/1473095203002001005

Housing Communities and Local Government Committee. (2018). Planning guidance on fracking: Eighth Report of Session 2017-19. Retrieved from https://publications.parliament.uk/pa/cm201719/cmselect/cmcomloc/767/767.pdf

Horowitz, L. S. (2013) Toward empathic agonism: conflicting vulnerabilities in urban wetland governance, Environment and Planning A, 45: 2344 - 2361 https://doi.org/10.1068/a45591

House of Commons, 2018. 12 $12^{\text {th }}$ Sept Westminster Hall debeate: Shale Gas Exploration: Planning Permission - (Vol 636 Col 328WH). Retrieved from https://hansard.parliament.uk/commons/2018-09-12/debates/BE489F18-2506-4AFD-BF840398580E1D2B/ShaleGasExplorationPlanningPermission

Ibrahim, N. A. (2018). Everyday authoritarianism: a political anthropology of Singapore. Critical Asian Studies, 50(2), 219-231. https://doi.org/10.1080/14672715.2018.1445538

This article is protected by copyright. All rights reserved 
Infrastructure

Act

(2015),

C.7.

Retrieved

from

https://www.legislation.gov.uk/ukpga/2015/7/contents/enacted

International Energy Agency. (2018). Key World Energy Statistics. Retrieved from https://webstore.iea.org/key-world-energy-statistics-2018

Jessop, B. (2019). Authoritarian Neoliberalism: Periodization and Critique. South Atlantic Quarterly, 118(2), 343-361. https://doi.org/10.1215/00382876-7381182

Johnson, B. (2020) 'PM Economy speech: 30th June 2020', Retrieved from https://www.gov.uk/government/speeches/pm-economy-speech-30-june-2020

Johnstone, P. (2010). The Nuclear Power Renaissance in the Uk: Democratic Deficiencies within the 'Consensus' on Sustainability. Human Geography, 3(2), 91-104. https://doi.org/10.1177/194277861000300207

Keeler, J. T. S. (2016). The Politics of Shale Gas and Anti-fracking Movements in France and the U.K. . In W. Y. \& W. E. Hefley (Eds.), The Global Impact of Unconventional Shale Gas Development: Economics, policy and Interdependence. Cham: Springer. 43-74.

Kundnani, A. (2021). The racial constitution of neoliberalism. Race \& Class, https://doi.org/10.1177/0306396821992706

Lancashire County Council. (2015). Development Control Comittee - Tuesday23rd June at 10:00 am in Council Chamber, County Hall, Preston. Retrieved from http://council.lancashire.gov.uk/documents/g4919/Public\%20reports\%20pack\%2023rd-Jun2015\%2010.00\%20Development\%20Control\%20Committee.pdf?T=10

Latour, B. (2012) Introduction: Paris, invisible city: The plasma. City, Culture and Society, 3 (2):91-93

Leadsom, A. (2019). Energy Policy Update: Written statement - HCWS68. Retrieved from https://questions-statements.parliament.uk/written-statements/detail/2019-11-04/HCWS68

Lefebvre, H. (1968). The Sociology of Marx. New York: Pantheon Books

Lefebvre, H. (1991) The Produdction of Space, Oxford, Blackwell

This article is protected by copyright. All rights reserved 
Luger, J. (2020). Questioning planetary illiberal geographies: territory, space and power. Territory, Politics, Governance, 8(1), 1-6. https://doi.org/10.1080/21622671.2019.1673806

Macfarlane, L. 'The Tories' planning overhaul is a ferocious attack on democracy' The Guardian (online).

Retrieved from https://www.theguardian.com/commentisfree/2020/aug/07/the-tories-planning-overhaul-is-aferocious-attack-on-democracy <Accessed 05/02/2020>

Marchart, O. (2007). Post-foundational political thought : political difference in Nancy, Lefort, Badiou and Laclau. Edinburgh: Edinburgh : Edinburgh University Press.

Marshall, T. (2013). The Remodeling of Decision Making on Major Infrastructure in Britain. $\begin{array}{llll}\text { Planning Practice } \quad \& \quad \text { Research, } & \text { 28(1), }\end{array}$ https://doi.org/10.1080/02697459.2012.699255

McGuirk, P. M. (2001). Situating Communicative Planning Theory: Context, Power, and Knowledge. Environment and Planning A, 33(2), 195-217. https://doi.org/10.1068/a3355

McLean, B. (2018). Saudi America: The Truth about Fracking and how It's Changing the World: Columbia Global Reports.

Ministry of Communities, Housing and Local Government (2018), National Planning Policy Framework, Retrieved from https://webarchive.nationalarchives.gov.uk/20181206183454/https://www.gov.uk/governmen t/publications/national-planning-policy-framework--2

Ministry of Housing Communities and Local Government. (2020). Planning for the Future: White Paper 2020 August Retrieved from https://assets.publishing.service.gov.uk/government/uploads/system/uploads/attachment_data /file/907647/MHCLG-Planning-Consultation.pdf

Ministry of Justice (2020). Government launches independent panel to look at judicial review [Online]. Retrieved from https://www.gov.uk/government/news/government-launchesindependent-panel-to-look-at-judicial-review [Accessed 07/12/2020].

Mouffe, C. (2005). On the Political. Abingdon: Routledge.

This article is protected by copyright. All rights reserved 
Netpol. (2017). Protecting the Planet is Not a Crime: A Netpol Report on the Policing of Anti-Fracking Protests During 2017. Retrieved from https://netpol.org/wpcontent/uploads/2017/11/Protecting-The-Planet-Is-Not-a-Crime.pdf

Olesen, K. (2014). The neoliberalisation of strategic spatial planning. Planning Theory, 13(3), 288-303. https://doi.org/10.1177/1473095213499340

Oosterlynck, S., \& Swyngedouw, E. (2010). Noise Reduction: The Postpolitical Quandary of Night Flights at Brussels Airport. Environment and Planning A: Economy and Space, 42(7), 1577-1594. https://doi.org/10.1068/a42269

Ormerod, E. and Davoudi, S. (2021) Governing the pandemic, democracy at the time of emergency, Town Planning Review, 92(3):323-327

Payne, S. (2020). 'Boris Johnson targets shake-up of English planning system', The Financial Times (London). Retrieved from: https://www.ft.com/content/7aaae327-fdcf-428a900f-5a809bfcd9ef

Peck, J. (2012). Constructions of neoliberal reason. Oxford: Oxford : Oxford University Press.

Peck, J., \& Theodore, N. (2019). Still Neoliberalism? South Atlantic Quarterly, 118(2), 245265. https://doi.org/10.1215/00382876-7381122

Perry, C. (2018). The Future is Beneath Us. Retrieved from https://www.gov.uk/government/speeches/the-future-is-beneath-us

Poulantzas, N. (2000). State, Power, Socialism (P. Camiller, Trans.). London: Verso.

Quinn, B., Elgot, J., Wainwright, O. 'England's planning changes will create 'generation of slums' The Guardian (online). Retrieved from https://www.theguardian.com/politics/2020/aug/05/englands-planning-reforms-will-creategeneration-of-slums <Accessed 05/02/2020>

Rancière, J. (1999) Disagreement. Minneapolis: University of Minnesota Press

This article is protected by copyright. All rights reserved 
Rudd, A. (2015). SHALE GAS AND OIL POLICY :Written statement - HCWS202. Retrieved from https://www.parliament.uk/business/publications/written-questions-answersstatements/written-statement/Commons/2015-09-16/HCWS202/

Rudd, A., \& Clark, G. (2015). Faster decision making on shale gas for economic growth and energy security Retrieved from https://www.gov.uk/government/news/faster-decisionmaking-on-shale-gas-for-economic-growth-and-energy-security

Schmitt, C. (1996). The concept of the political. Chicago: University of Chicago Press.

Slade, D., Gunn, S., \& Schoneboom, A. (2019). Serving the Public Interest? The reorganisation of $U K$ plannig services in an era of reluctant outsourcing. Retrieved from https://www.rtpi.org.uk/media/3220094/serving_the_public_interest_-_v2_-_2019.pdf

Sparke, M. (2020) Comparing and connecting territories of illiberal politics and neoliberal governance, Territory, $\quad$ Politics, $\quad$ Governance, 8 95-99 https://doi.org/10.1080/21622671.2019.1674182

Speed, S. (2018). The Battle of Barton Moss. In T. Geelan, M. González Hernando, \& P. W. Walsh (Eds.), From Financial Crisis to Social Change: Towards Alternative Horizons. Cham: Springer, 129-148.

Swinford, S. (2020), 'I'll take an axe to planning laws, says Dominic Cummings' The Times (online). Retrieved from https://www.thetimes.co.uk/article/ill-take-axe-to-planning-lawssays-cummings-bwn5j3b88 <Accessed 05/02/2020>

Swyngedouw, E. (2010). Apocalypse Forever? Theory, Culture \& Society, 27(2-3), 213-232. https://doi.org/10.1177/0263276409358728

Talk Fracking. (2019). Talk Fracking NPPF Legal Challenge Legal Briefing Paper. Retrieved from http://www.talkfracking.org/wp-content/uploads/2019/05/Talk-Fracking-NPPF-LegalChallenge-Legal-Briefing-Paper-17-05-2019.pdf

Tansel, C. B. (2019). Neoliberalism and the Antagonisms of Authoritarian Resilience in the Middle East. South Atlantic Quarterly, 118(2), 287-305. https://doi.org/10.1215/003828767381146

This article is protected by copyright. All rights reserved 
The Royal Society, \& Royal Academy of Engineering. (2012). Shale gas extraction in the UK: a review of hyraulic fracturing. Retrieved from www.royalsociety.org/policy/projects/shale-gas-extraction

Thomson, S. and Ip, E. 2020, COVID-19 emergency measures and the impending authoritarian pandemic, Journal of Law and the Biosciences, 1-33, https://doi.org/10.1093/jlb/lsaa064

Thornley, A. (1990). Urban planning under Thatcherism : the challenge of the market. London

UK Government. (2015). Infrastructure Act. Retrieved from http://www.legislation.gov.uk/ukpga/2015/7/section/41

Unknown Author (2016) Lancashire CC fracking decision June 2015, [Video] Youtube, Retrieved from https://www.youtube.com/watch?v=lAu6b7gm8Js

Vaughan, A. (2016). UK ministers make it 'top priority' to ensure nature laws do not hamper $\begin{array}{llll}\text { fracking. } & \text { The } & \text { Retrieved }\end{array}$ https://www.theguardian.com/environment/2016/feb/01/uk-ministers-make-it-top-priority-toensure-nature-laws-do-not-hamper-fracking

Watt, N. (2014). Fracking in the UK: 'We're going all out for shale' admits Cameron. Retrieved from https://www.theguardian.com/environment/2014/jan/13/shale-gas-frackingcameron-all-out

Whitton, J., Brasier, K., Charnley-Parry, I., \& Cotton, M. (2017). Shale gas governance in the United Kingdom and the United States: Opportunities for public participation and the implications for social justice. Energy Research \&amp; Social Science, 26, 11-22 https://doi.org/10.1016/j.erss.2017.01.015

Wigger, A. (2019). The new EU industrial policy: authoritarian neoliberal structural adjustment and the case for alternatives. Globalizations, 16(3), 353-369. https://doi.org/10.1080/14747731.2018.1502496

Wildavsky, A. (1973) If planning is everything, maybe it's nothing. Policy Sciences, 4, 127153.

This article is protected by copyright. All rights reserved 
Williams, L., Macnaghten, P., Davies, R., \& Curtis, S. (2017). Framing 'fracking': Exploring public perceptions of hydraulic fracturing in the United Kingdom. Public Understanding of Science, 26(1), 89-104. https://doi.org/10.1177/0963662515595159

This article is protected by copyright. All rights reserved 